\title{
Stage 0 Chronic Lymphocytic Leukemia
}

National Cancer Institute

\section{Source}

National Cancer Institute. Stage O Chronic Lymphocytic Leukemia. NCI Thesaurus. Code C7847.

Risk: Low; Findings: Lymphocytosis only; Survival (months): more than 120. (from AJCC 8th Ed.) 